\title{
USACE PREPARATION AND RESPONSE TO 2017 HURRICANES HARVEY, IRMA, AND MARIA
}

\author{
Mary A. Cialone, Jane M. Smith, Julie D. Rosati, Michael L. Follum, T. Chris Massey, Andrew J. \\ Condon, and Robert C. Thomas \\ U.S. Army Corps of Engineers, Mary.A.Cialone@usace.army.mil, Jane.M.Smith@usace.army.mil, \\ Julie.D.Rosati@usace.army.mil, Michael.L.Follum@erdc.dren.mil, Chris.Massey@erdc.dren.mil, \\ Andrew.J.Condon@usace.army.mil, Robert.C.Thomas@usace.army.mil
}

\begin{abstract}
INTRODUCTION
The year 2017 was an extremely active hurricane season with five hurricanes that reached major hurricane strength (Category 3 or higher) on the United States (U.S) or the Caribbean coast. This paper focuses on the U.S. Army Corps of Engineers (USACE) preparation and response to the three most destructive events (Hurricanes Harvey, Irma, and Maria). Each of these storms posed unique challenges to the people and infrastructure in its path.
\end{abstract}

\section{HISTORY}

Hurricane Harvey made landfall in the U.S. three times in August 2017 (first as a Cat 4) and was most notable for the extreme rainfall as this slow moving storm meandered along coastal Texas. Many areas received more than 100 $\mathrm{cm}$ of rainfall, with one area receiving close to $165 \mathrm{~cm}$ in a 4-day period. The Houston-area storm water drainage systems could not accommodate this unprecedented rainfall, leading to thousands of flood water rescues, displaced homeowners, billions of dollars in damage, and 89 deaths. Hurricane Irma was the first Cat 5 storm of the 2017 season and was most notable for its path of destruction through the Caribbean and Florida Keys, then bisecting the entire length of Florida. On 6 Sep, Irma had the strongest Cat 5 wind speed of the 2017 season (83 $\mathrm{m} / \mathrm{s}$ ), but its minimum central pressure of $914 \mathrm{mb}$ was not as intense as Hurricane Maria that followed 2 weeks later. Hurricane Maria was one of the top ten most intense storms in the Atlantic Basin with a minimum pressure of $908 \mathrm{mb}$ and a Cat 5 wind speed of $78 \mathrm{~m} / \mathrm{s}$. Making landfall in Dominica as a Cat 5 on $18 \mathrm{Sep}$, it was considered the worst natural disaster in recorded history for this region, compounded by the previous strike of Irma and the close passage of Jose. Maria struck Puerto Rico on 20 Sep, causing a major humanitarian crisis due to the complete loss of the electrical grid, lack of resources, and the difficulty in bringing relief to an island territory. The purpose of this paper is to (1) describe USACE District response and USACE Engineer Research and Development Center (ERDC) model applications for the preparation before and recovery after these storms and (2) document future $R \& D$ requirements to improve resilience and reduce the risk from future disasters.

\section{PREPARATION, RESPONSE, AND RECOVERY}

USACE Flood Risk Management is described as a fourphase process: preparedness, response, recovery, and mitigation to achieve functional performance under the stress of disturbances. In addition, USACE has the authority under Public Law 84-99 (Flood Control and Coastal Emergency Act) for emergency management activities and can undertake activities including disaster preparedness (advanced measures), emergency operations (flood response and recovery), rehabilitation of flood control works threatened or destroyed by flood, protection or repair of federally-authorized shore protective works threatened or damaged by coastal storms, and provisions of emergency water due to drought or contaminated source (mitigation). In advance of the 2017 hurricane season, preparedness was exemplified by the USACE Jacksonville District implementing lessons learned from prior tropical events. An emergency action plan developed for the Herbert Hoover Dike surrounding Lake Okeechobee, Florida, was reviewed prior to Hurricane Irma in order to refine the risk assessment methodology to be implemented as a function of National Hurricane Center forecasts. Prior to Irma's U.S. landfall, the risk assessment methodology was implemented and communicated between the National Weather Service and USACE emergency managers twice daily. Water levels were monitored during Irma and USACE inspection teams were deployed immediately following the storm to survey the dike and collect high-water mark data. Measurements were compared to two forecast models. From these data, more detailed hydrodynamic modeling was recommended to better prepare for potential future storms and develop mitigation alternatives.

\section{APPLICATION OF ERDC R\&D TOOLS}

ERDC R\&D storm surge and inland flood modeling tools were applied to assist in the preparation and response for all three hurricanes. Applications of the Advanced Circulation (ADCIRC) model (Luettich et al., 1992) for the Texas coast (Harvey) and Lake Okeechobee (Irma) were made to provide surge forecasts to District emergency managers. Figure 1 and Figure 2 show the simulated maximum water level envelope forecast for the Texas Coast and Lake Okeechobee, respectively. Prior to Hurricane Maria making landfall in Puerto Rico, ERDC applied a rapid numerical modeling tool to estimate inland flooding (AutoRoute) (Follum et al., 2016). AutoRoute used 100-yr flow estimates, high resolution elevation data (Krieger et al., 2007; Taylor et al., 2008; Wendleder et al., 2013), and land cover (Homer et al., 2004) to simulate flood inundation over large extents using high density, automated cross sections. Flood inundation maps for the entire island were simulated in less than one day using the flow estimates (Figure 3 ). The full paper will provide details of USACE preparation and response to these three major hurricanes, both in terms of physical response and recovery as well as application of ERDC numerical model research tools. 


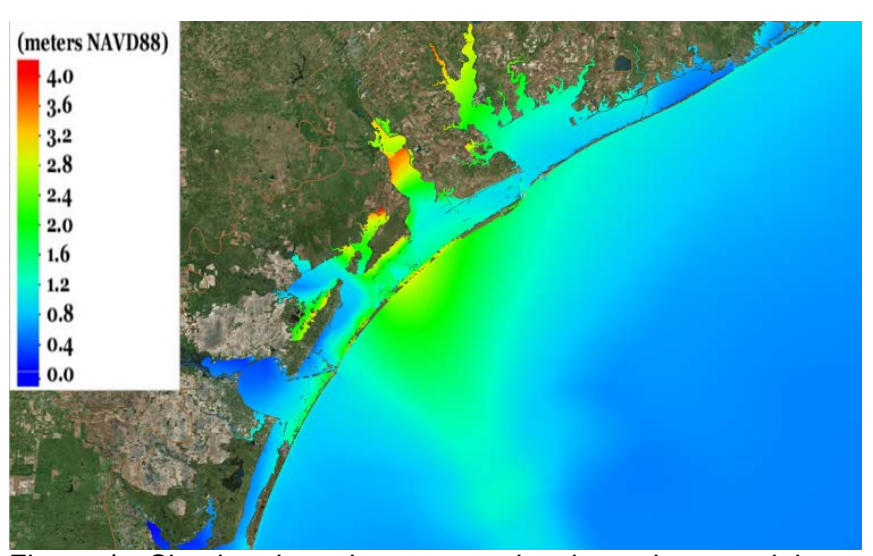

Figure 1. Simulated maximum water level envelope model forecast for the Texas coast in response to Hurricane Harvey.

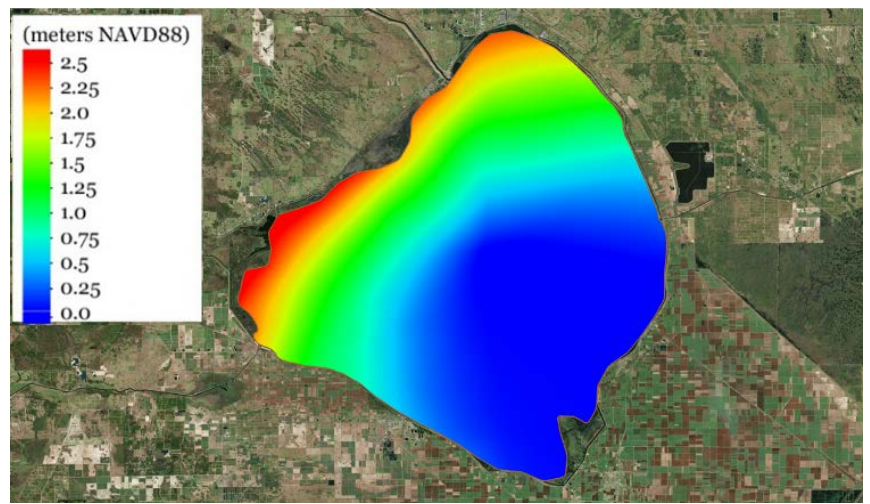

Figure 2. Simulated maximum water level envelope model forecast for Lake Okeechobee in response to Hurricane Irma.

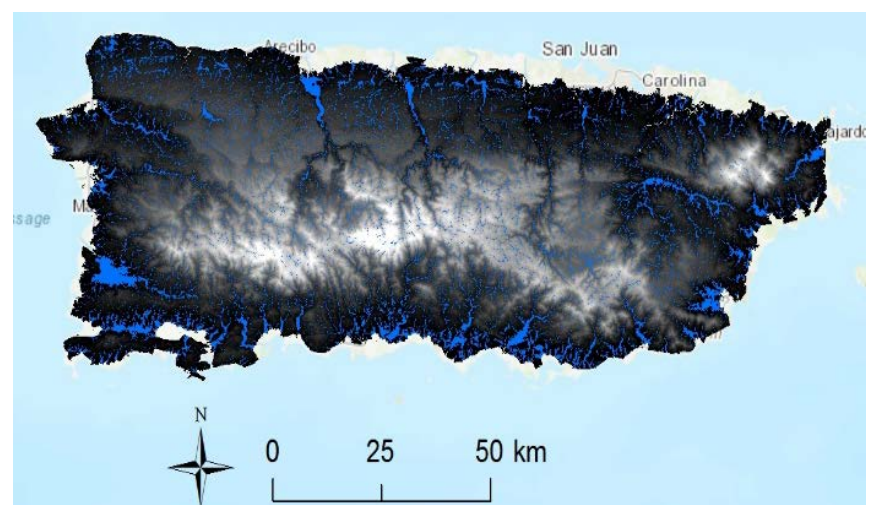

Figure 3. Simulated 100-year flood inundation map for Puerto Rico in response to Hurricane Maria.

\section{REFERENCES}

Follum, M. L., Tavakoly, A. A., Niemann, J. D., \& Snow, A. D. 2016. AutoRAPID: A Model for Prompt Streamflow Estimation and Flood Inundation Mapping over Regional to Continental Extents. JAWRA Journal of the American Water Resources Association, 80523, 1-20. https://doi.org/10.1111/1752-1688.12476

Homer, C., Huang, C., Yang, L., Wylie, B. \& Coan, M. 2004. Development of a 2001 National Landcover Database for the United States. Photogrammetric Engineering and Remote Sensing, Vol. 70, No. 7, July 2004, pp. 829-840.

Krieger, G., Moreira, A., Fiedler, H., Hajnsek, I., Werner, M., Younis, M., \& Zink, M. 2007. TanDEM-X: A satellite formation for high-resolution SAR interferometry. IEEE Transactions on Geoscience and Remote Sensing, 45(11), 3317-3340. https://doi.org/10.1109/TGRS.2007.900693

Luettich, R.A., Jr., Westerink, J.J., and Scheffner, N.W. 1992. ADCIRC: an advanced three-dimensional circulation model for shelves coasts and estuaries, Report 1: Theory and Methodology of ADCIRC-2DDI and ADCIRC-3DL, Dredging Research Program Technical Report DRP-92-6, U.S. Army Engineers Waterways Experiment Station, Vicksburg, MS, $137 p$.

Taylor, L.A., Eakins, B.W., Carignan, K.S., Warnken, R.R., Sazonova, T., Schoolcraft, D.C. 2008. Digital Elevation Models of Puerto Rico: Procedures, Data Sources and Analysis, NOAA Technical Memorandum NESDIS NGDC-13, National Geophysical Data Center, Boulder, CO, 27 pp.

Wendleder, A., Wessel, B., Roth, A., Breunig, M., Martin, K., \& Wagenbrenner, S. 2013. TanDEM-X water indication mask: Generation and first evaluation results. IEEE Journal of Selected Topics in Applied Earth Observations and Remote Sensing, 6(1), 171179. https://doi.org/10.1109/JSTARS.2012.2210999 